\title{
Empirical Testing Of Different Alternative Proxy Measures For Firm Size
}

Osamah M. Al-Khazali, (E-mail: Kazali@ausharjah.edu), American University of Sharjah, UAE Taisier A. Zoubi, (E-mail: tzoubi@ausharjah.edu), American University of Sharjah, UAE

\begin{abstract}
This paper examines the relationship among total sales revenue, total assets, book value of equity, and market value of equity for different economic sectors and time periods. Five statistical tools are used to examine the relationship among the different proxies of size of the firm for the period 1999-2002. Our study shows that the relationships among the four measures of the size of the firm are not the same for the different economic sectors and are not stable over time for each economic sector. Our results suggest that the use of the four measures interchangeably as a proxy for the firm size may not be appropriate.
\end{abstract}

\section{INTRODUCTION}

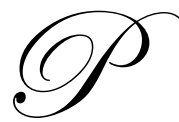

revious studies have used total sales revenue, total assets, book value equity, or market value of equity as proxy for size of firm. ${ }^{1}$ The use of these four measures interchangeably by the prior studies implies that these four measures are highly correlated with each other. Therefore, the use of one of these measures could be a proxy for the other three measures and the size of firms. The four measures may be highly correlated for some industries and not for others. Therefore, the use of one of these measures may not be appropriate proxy for one of the other three measures. To our knowledge, the relationship among the four measures of the size of the firm and the interchangeability among them have not been examined by prior studies. The purpose of this research is to examine the relationship between total sales revenue, total assets, book value of equity, and market value of equity for different industries and time periods. More specifically, we will examine empirically the degree of association among the four measures of the size of the firm and the characteristics of each measure for each industry.

The reminder of this paper proceeds as follows: Section 2 discusses the relevant, literature and points out several problems that arise when using different proxies in cross-sectional studies, section 3 provides a description of the data selection and methodology, section 4 provides the results and interpretation, and section 5 summarizes.

\section{REVIEW OF LITERATURE}

Almost all prior empirical studies in accounting and finance have used either total assets (see Lougee and Marquardt, 2004; Daley, 1984; and Foster, 1977), total sales (see Shehata, 1991), book value of equity (see Kasznok and Mcnichols, 2002; Bowen, 1981; and Beaver, Griffin, and Landsman, 1982), or market value of equity (see Biddle and Lindhal, 1982; Christie, 1987; Ball and Kothari, 1991; and Berk, 1995; Kim, 1997; Kousenidis, Negakis, and Foropoulos, 2000; Chariton, Clubb, and Andreon, 2001) as a proxy for the firm size. Firm size has been used for four purposes: 1) to proxy for many different constructs such as the political costs, information production costs, and competitive advantages, 2) effect on stock returns, 3) to eliminate heteroscedasticity problems, and 4) to explain exporters' behavior.

Accounting researches have used firm size to explain differences across firms in their accounting method and corporate disclosure decisions [Jensen and Meckling, 1978; Deakin, 1979, Zmijewski and Hagerman, 1981; Zimmerman, 1983; Hughes and Ricks, 1984; Collins, Rozeff, and Dhaliwal, 1981; and Shehata, 1991]. For example, Hughes and Ricks (1984) used market value of stockholder's equity plus book value of debt as a proxy of the size of firms in order to measure the degree of exposure to political costs. Collins, Rozeff, and Dhaliwal (1981) examined 
the impact of eliminating the full cost method of accounting on the stock returns of the oil and gas firms and on the cross-sectional variation of the stock returns of the affected firms. The size of the firm was used to test the crosssectional variation of the stock return. In the mean time, the size of the firm was measured by the book value of debt, book value of preferred stock, and market value of equity. Shehata (1991) used size of the firm as one of the determinants of the choice of accounting methods. He used total sales as a proxy for the size of the firms. However, when he examined the determinants of whether to expense or capitalize research and development costs, total assets was used as a proxy for the size of firms. Salamon and Dhaliwal (1980) examined the relationship between the level of voluntary financial disclosure and the size of the firm measured by total assets. Their results indicate that firms which voluntarily disclosed financial information such as segmental sales and earnings data are significantly larger than the diversified firms that didn't voluntarily disclose such data.

Other studies examined the cross sectional differences in the security price reactions to earnings announcements of firms or economic news which are associated with firm size [Atiase, 1985; Ball and Kothari, 1991; and Shehata, 1991; Kim, 1997; Chariton, Clubb, and Anderson, 2001]. For example, Atiase (1985) found that the degree of unexpected security price changes in response to earning reports was inversely related to the firm size, measured by the market value of equity of the firm. Ball and Kothari (1991) examined the relationship between the amount of information arrival around earnings announcements and size of the firm measured by market value of common equity. Their results show that the amount of information arrived around earnings announcements is higher for larger firms than those for smaller firms. Berk (1995) contended that firm size, measured by market value of equity, should be viewed as evidenced of model misspecifications rather than an anomaly.

Kim (1995) used the market value of equity as a measure of size of the firm and found that size is statistically significant in explaining security returns. Kim (1997) examined the effect of firm size, book-to-market, and price earnings on expected stocks returns. Kim found that firm size is marginally significant in explaining average stock returns, but insignificant when quarterly returns are used. Kim's findings indicate that the firm size is sensitive to the measurement intervals. The result's of Kim's study in 1997 is not consistent with 1995 study in spite of the use of the market value of equity as a proxy for size of the firm. The inconsistency in the results may be partly due to the differences in the samples. Kim (1995) used non-financial firms only while Kim (1997) used all firms.

Chariton, Clubb, and Anderson (2001) hypothesized that security returns response to both unexpected earnings and cash flows will be lower (higher) for large (small) firms when unexpected earnings and cash flows data are used jointly to explain security returns. They used market value of common equity as a proxy for the firm's size. Their results indicate that the coefficient of unexpected earnings is lower for larger firms. The results also show that there was a relationship between prior period cash flows and security returns for larger firms but not for smaller firms. However, French and Fama (1992) found that there was association between prior period cash flows and security returns for both larger and smaller firms. Although both studies used the same measure of the size of the firm, their results are different. Different sample selection criteria and different time periods may have produced different sample sizes and different composition of samples.

The association among firm size, security returns, and unexpected earnings has been examined by many prior studies (see for example, Foster, Olsen, and Shevlin, 1984; Kross and Schroeder, 1989; Stickel, 1992). Foster, Olsen, and Shevlin, (1984) found that size of the firm, measured by market value of common equity, has an impact on abnormal returns. Smaller firms showed more negative abnormal returns than larger firms when unexpected earnings are negative. Their results also indicate that for positive unexpected earnings, smaller firms have more positive abnormal returns than larger firms. Their sample consists of 2053 firms (63000 firm-quarter observations) from 1974 to 1981. Kross and Schroeder (1989) used a different sample (296 firms) and different period (1978 - 1980) to test the relation between firm size and security returns and unexpected earnings. They found similar results to those found by Foster et., (1984). Shevlin and Shores (1993) used 11990 firm-quarterly observations for the period of 1979 1987 and found that there is an association between firm size and cumulative abnormal returns surrounding quarterly earning announcements.

Lougee and Marquardt (2004) examined the relationship between GAAP earnings and pro forma earnings and its incremental information content above GAAP earnings. The results indicate that firms with low GAAP 
earnings are more likely to disclose pro forma earnings. The results also show that pro forma earnings are more useful than low GAAP earnings. They used a control sample by matching them with their sample based on four-digit SIC industry codes and firm size measured by total assets.

Das, Levine and Sivaramakrishnan (1988) examined whether the predictability of earnings based on past information is a determinant of the cross-sectional difference in forecast bias. The size of the firm, measured by market value of equity, is included in the model to control the amount of information disclosed and the number of analysts following the sampled firms. Their results indicate that financial analysts forecast optimism is less for large firms than for smaller firms.

Kasznok and Mcnichols (2002) examined the relationship between firms meeting earning expectation and the abnormal return. They control for the size of the firms by including the book value of equity. Their results showed higher abnormal returns for firms whose actual earnings met the earnings expectation than those firms whose earnings did not meet expectations.

Size of firm had also been used to deflate the independent variable in the cross-sectional studies in order to overcome heteroscedasticity problem. The hetroscedasticity problem involves the nonuniformity of error variances between companies which results in an incorrect estimation of standard errors of regression coefficients. Atiase and Tse (1989) contended that the heteroscedasticity problem can be treated by deflating the regression equation by a variable thought to be proportional to the true standard deviation of the error term.

Since error variances may be depend on size of firms, typical deflating variables have been total sales revenue [Beaver, Griffin, and Landsman, 1982; Foster, 1980], total assets [Foster, 1977; Daley, 1984], the book value of common stocks [Bowen, 1981; and Beaver, Griffin, and Landsman, 1982], and the market value of equity [Biddle and Lindhal, 1982; Christie, 1987; and Ball and Kothari, 1991]. For example, Foster (1977), and Daley (1984) used book value of firm assets as a deflating variable. Bowen (1981) utilized the book value of the firm's equity at the beginning of the period as a deflating variable. Foster (1980) used two different deflating variables: gross revenues and market value of common equity at fiscal year-end. Collins, Rozeff, and Dhaliwal (1981) used three different deflators to deflate three different independent variables that were included in the cross-sectional regression model. Beaver, Griffin, and Landsman (1982) used sales and book values of common equity as deflating variables. Ball and Kothari (1991) deflated earnings before extraordinary items and discontinued operations by the market value of equity. Brown, Foster, and Noreen (1984) used the average absolute change of the earning as a deflator. Biddle and Lindhal (1982) considered two deflators: the market value of equity and the last period's value of series. Their results were not sensitive to choice of deflators. Chrisite (1987) suggested that the market value of equity at the beginning of the period is an appropriate deflator for cross-sectional return studies. Ayers, Cloyd, and Robinson (2002) used firm's market value of equity at year-end as proxy for size of the firm. They examined the impact of Revenue Reconciliation Act of 1993 on stock returns of the affected firms. The results of this study indicate that size is an important factor in explaining stock returns.

Finally, several studies examined the impact of firm size on the export performance. The results of these studies are mixed. Some studies have found no relationship between firm size and export success (Holzmuller and Kasper 1991; Bonaccorsi 1992; and Moini 1995). Others found a negative relationship between firms size and export growth (Cooper and Kleinschmidt, 1985), while other researchers found a positive relationship (Reid 1982; Kaynak and Kothari, 1984; and Christensen, De Rocha, and Gertner, 1987). Reid (1982), for example, reported that larger firms are less constrained in devoting financial and human resources to export. It seems no definitive conclusions can be drawn from past research on the relationship between export success and the size of the firm. As is evident from the conflicting results of the prior studies, there is no consensus with regard to the impact of size on export behavior. The different results could be explained by measurement associated with the size of the firm on the hand and the statistical procedures used in the estimation on the other hand.

The prior studies, irrespective of how they used size of the firm, reached conflicting results. The use of the same proxy for different industries, different composition of the samples, different time periods, and/or different 
proxies for size by different researchers in examining the same research question may have caused the inconsistency in the results of most prior studies.

\section{DATA AND METHODOLOGY}

A firm is included in the sample if it has a complete data from 1999 to 2002 available on the COMPUSTAT. The data set include the following: total assets (TA), total sales revenue (SALE), book value of common equity (BV), and market value of common equity (MVE). The initial sample consisted of 10,029 firms for the period 1999-2002. After applying the criteria above, the sample is reduced to 6,057 firms. Firms are divided into ten sub-samples based on the Global Industry Classification Standard Code (GICS). The GICS was formed as a result of the collaboration effort between Standard's \& Poor's and Morgan Stanley Capital International. GICS is based on a classification of economic sectors. GICS can be subdivided into hierarchy of industry groups, industry and sub-industries. We used the economic sector classification (two-digit) to ensure that we have enough firms in each sub-sample. Using 4, 6, or 8 GICS digit codes would have produced sub-sample with very small number of firms which would not allow us to conduct our research objectives. The ten industries identified include Energy, Materials, Industries, Consumer Discretionary, Consumer Staples, Health Care, Financials, Information Technology, Telecommunication Services, and Utilities.

The number of firms in each economic sector for the period of the study is presented in Table 1. Telecommunication Services sector sub-sample has the least number of firms. The vast majority of firms are in the Information Technology sector. The samples can be viewed as populations or as representative samples from some undefined population. In either case the results of this study should be generalizable to the population.

To address the use of each measure as a proxy for the size of the firm and to examine the differences and similarities among the four different measures for the ten different economic sectors, five statistical tools are utilized in this study: Correlation, Analysis of variances, Kruskill-Wallis, Levene's Test, and Bartlett's test.

Correlation coefficients among TA, SALE, BV, and MVE are calculated for each industry and year to examine the degrees of association among the four measures of size for each sector sample and for the entire combined sectors sample. Furthermore, to test the differences of distributions across the different economic sectors for each measure of the size of firm, test for equality of means and variances were used in this study. To test for equality of means ANOVA- F test and Kruskill-Wallis test are used. Levene's test and Bartlett's test are used to examine the equality of variance. Levene's test is used because it allows testing more than two samples at once. It is also less sensitive to outliers and the violation of normality assumption is not a major problem. Bartlett's test is used for testing equality of variances of several independent samples. Sample sizes of the different populations do not have to be the same. But normality is essential for this test.

\section{RESULTS}

In order to test the relationship between TA, SALE, BV, and MVE, simple correlation coefficients are calculated for each industry and each year. There are six possible combinations among these variables each year of the period of the study $(1999,2000,2001$, and 2002).

The results of the correlation coefficient for 1999, presented in Table 2 - Panel A, show that the relationship between TA and BV are the strongest for materials $(r=0.5948)$, consumer discretionary $(r=0.61093)$, financials $(r=$ 0.7960), information technology $(r=0.7949)$, and telecommunication services $(r=0.7407)$ sectors compared with other correlations among the four proxies. The correlation between SALE and MVE, TA and MVE, and BV and MVE are the weakest for 1999 for all sectors except the information technology.

Table 2 - Panel B presents the correlation coefficients among the four measures for size of the firm for 2000. The results indicate that the highest correlation coefficient for 2000 is between TA and BV which is consistent with the 1999 results. Seven of the ten sectors produce highest correlation between TA and BV for both years 1999 and 
2000. However, the highest correlation for all the sectors combined is found between BV and MVE which is inconsistent with the results of the individual sectors correlations.

The correlation coefficients for the year 2001 are presented in Table 2-Panel C. The weakest correlation for the year 2002 is between TA and MVE for the following sectors: energy $(\mathrm{r}=0.3461)$, materials $(\mathrm{r}=0.3813)$, consumer discretionary $(r=0.2827)$, consumer staples $(r=0.3448)$, information technology $(r=0.4682)$, and utilities $(r=0.4728)$ and that happens to be the weakest of the combined samples of all economic sectors $(r=0.5181)$.

However, the results of the correlation for 2001 and 2002 are not consistent with our findings for 1999 and 2000. The correlation coefficients for BV and MVE are the strongest for seven sectors in 2001 and 2002 while they were not for 1999 and 2000. Furthermore, the relationship between BV and MVE persists for the combined overall sample for all the sectors. Table 2-Panels A, B, C, and D (see last row) indicates that the strongest relationship for the combined overall sample for all the sectors is between BV and MVE and the weakest is between TA and MVE for the four years. However, such relationship does not hold for each sector.

As the results shown in Table 3, there is a lack of pattern of correlations among the four measures across the different economic sectors. The correlation is strong for some measures and some sectors while weak for other measures and other sectors for the same time period. Furthermore, the relationships among the measures are not stable over time although the same firms were used over the time period of this study.

In summary, the results of the correlation indicate that the correlation coefficients among the four proxies of the size of the firm differ across different types of economic sectors and the overall population for each year. The implication is that the use of the four different proxies for the size of the firm interchangeably for different economic sectors may not be appropriate since the relationship among the four measures is not a one-to-one relationship. To understand the characteristics of the four measures of the size of the firm, four different descriptive statistics were computed for each year and each economic sector. Table 3 Panels A, B, C, and D presents the mean, median, Kurtosis, and skewness. As can be seen in Table 3, the means of the different sectors are different for each year of the test period and different from the overall mean of the combined samples. To examine whether the differences between the means are statistically significant, ANOVA and Kruskall-Wallis statistical test will are conducted.

The medians for the ten different sectors vary across samples and overtime. The Kurtosis and Skewness results reveled that the statistical distributions of the ten sectors are different from one another.

The results of the test of equality of means for the ten different sectors are presented in Table 4. Analysis of variance (ANOVA) test and Kruskall-Wallis test are used to examine the differences among the means of the ten sectors for each year of the test period. The ANOVA test allows us to determine whether differences exist between two or more population means. The results of ANOVA presented in Table 4 indicate that the F-values for every measure of the size of the firm and every year are greater than the critical value $\mathrm{F}=1.88$ for $5 \%$ level of significance Hence, we have sufficient evidence to reject the null hypothesis that the means of the ten different sectors are equal at $5 \%$ level of significance. In other words, the analysis of variance supports the conclusion that the population means of the ten different sectors for the four different measures of the size of the firm are not equal. However, the Kurtosis and Skewness tests results revealed that the populations of the ten different sectors are not normally distributed and do not have equal variance.

If the populations are not normally distributed and the variances of the different populations are unequal, then Kruskall-Wallis would be more appropriate test than the ANOVA test. The results of the Kruskall-Wallis test, presented in Table 5, indicate that the means of the ten different sectors populations are significantly different from each other, at $5 \%$ level of significance.

We compare the data distributions of the four measures for the different economic sectors using Levene and Bartlett tests. Levene's test and Bartlett's test are used to examine the difference in the variances. The results of both tests are presented in Table 4. 
According to the results of Levene's test, we can reject the hypothesis that all variances are equal at $5 \%$ level of significance. However, according to Conover, Johnson, and Johnson (1981), Bartlett's test is more appropriate for examining the equality of variance than Levene's test when the sample sizes are not equal. As shown in Table 1, sample sizes for different economic sectors are not the same. Hence, the use of Bartlett's test would be more suitable than Levin's test for our data. The results of Bartlett's test show that the variances of SALE measure are not equal for the ten different economic sectors for each of the test years. Similar results were obtained for the TA, BV, and MVE measures. This lead us to conclude that the variances for all four measures across the ten different sectors for 1999, 2000, 2001, and 2002 are heterogeneous.

The results lead us to conclude that the use of any of the four measures for all sectors as deflating variable, as was done by many prior studies (see Daley, 1984; Beaver, Griffin, and Landsman, 1982; Biddle and Lindhal, 1982; and Ayers, Cloyd, and Robinson, 2002), may not solve the problem of the hetroscedascity since the populations of the prior studies were taken from different economic sectors.

\section{CONCLUSION}

Prior studies have used total assets, total sales revenue, book value equity, and market value of equity as proxies for the size of firms. The purpose of this study is to investigate the relationships among total sales revenue, total assets, book value equity, and market value of equity for different economic sectors and time periods. The relationship among the different proxies for firm size has been tested empirically. Four proxies for size of the firm have been used to test the relationship.

In general, the results of this study indicate that the correlation coefficient between TA \& BV, TA \& MVE, and MVE \& BV are mixed. The results also show that the relationships are not stable over the period 1999-2002 for each economic sector and all the sectors combined. However, the relationships between TA \& SALE, SALE \& BV, and SALE \& MV are very weak. Furthermore, the results suggest that the degree of correlation among the four measures depends upon the type of economic sector and the time period. For example, the correlation coefficient between BV \& MVE is 92\% for telecommunication services for the year 2000 while it was $33 \%$ for 1999.

The results of this study suggest that the use of the four measures interchangeably as proxies for the firm size by the prior studies may not be appropriate. This could partially explain the inconsistent results of the prior research with respect to size of firm. For example, Watts and Zimmerman (1978) reported that the coefficient of firm size variable is positive and has the highest $t$-statistics of all the independent variables. In addition, the coefficient of size is the most stable across various sub samples. However, Bowen, Noreen, and Lacey (1981) found differences within their samples. In the final analysis, it may be that the variable which should be used as a proxy for size of firm is industry-specific that the generalizations from prior empirical research are not possible.

\section{SUGGESTIONS FOR FUTURE RESEARCH}

This study has examined empirically the relationship among four measures of the size of the firm and found that the relationship is not the same for the different economics sectors and over time. Although the results are interesting, it is important to note that the conclusion of this study based on a data of a short period of time. To improve the generalizability of this study, a longer period should be examined. Furthermore, to test the validity of the finding of this study, replication of some of the prior research would be warranted to test the validity of the findings of this study. This study subdivided the sample into different economic sectors using GICS classification codes. To examine the validity of the conclusion of this study, it would fruitful to examine the relationship among the four measures using SIC classification codes

\section{REFERENCES}

1. Atiase, R. Predisclosure Information, Firm Capitalization, and Security Price Reaction around Earnings Announcement, Journal of Accounting Research, Vol. 23, No. 1, pp. 21-36, 1985. 
2. Atiase, R. and Bamber, L. Timeliness of Financial Reporting, the Firm Size Effect, and Stock Price Reactions to Annual Earnings Announcements, Contemporary Accounting Research, 5, No. 2, 526-553, 1989.

3. Ayers, Benjamin, Bryan C. Cloyd, and John Robinson. The Effect of Shareholder-Level Dividend Taxes on Stock Prices: Evidence from the Revenue Reconciliation Act of 1993, The Accounting Review, Vol. 77, No. 4, pp. 933-947, 2002.

4. Ball, R. and S. Kothari. Security Returns Around Earnings Announcements, The Accounting Review, Vol. 66, No. 4, pp. 718-739, 1991.

5. Beaver, W., P. Griffin., and W. Landsman. The Incremental Information Content of Replacement Cost Earnings, Journal of Accounting and Economics, Vol. 4, No.1, pp.15-29, 1982.

6. Berk, Jonathan B. A Critique of Size-Related Anomalies, Review of Financial Studies, Vol. 8, No. 2, pp. 273-286, 1995.

7. Biddle, G. and F. Lindhal. Stock Price Reactions to LIFO Adoptions: The Association between Excess Returns and LIFO Tax Savings, Journal of Accounting Research, Vol. 20, No. 2, pp. 551-588, 1982.

8. Bonaccorsi, A. On the Relationship between Firm Size and Export Intensity, Journal Of International Business Studies, (1992), Vol. 23, No. 4, pp. 605-656.

9. Bowen, R. Valuation of Earnings Components in the Electric Utility Industry, Accounting Review, Vol. 56, No. 1, pp. 1-22, 1981.

10. Bowen, R., E. Noreen, and J. Lacey. Determinants of the Corporate Decision to Capitalize Interest, Journal of Accounting and Economics, Vol. 3, No. 2, pp. 151-179, 1981.

11. Charitou, Andreas, Colin Clubb, and Andreas Andreou. The Effect of Earnings Permanence, Growth and Fund Size on the Usefulness of Cash Flows and Earnings in Explaining Security Returns: Empirical Evidence for the UK, Journal of Business Finance \& Accounting, Vol. 27, No. 5, pp. 563-594, 2001.

12. Christensen, C., A. De Rocha, and R. Gertner. An Empirical Investigation of the Factors Influencing Export Success of Brazilian Firms, Journal of International Business Studies, Fall, 1987, Vol. 18, No. 3, pp. 61-77, 1987.

13. Christie, A. On Cross-Sectional Analysis in Accounting Research, Journal of Accounting and Economics, Vol. 9, No. 2, pp. 231-258, 1987.

14. Collins, D., M. Rozeff, and D. Dhaliwal. The Economics Determinants of the Market Reaction to Proposed Mandatory Accounting Changes in the Oil and Gas Industry: A Cross-Sectional Analysis, Journal of Accounting and Economics, Vol. 3, No. 1, pp. 37-71, 1981.

15. Conover, W., M. E. Johnson, and M. M. Johnson. Ä Comparative Study of Test of Homogeneity of Variances with Application the Outer Continental Shelf Bidding Data, Techometrics, Vol. 23, No. 4, pp. 351-361, 1981.

16. Cooper, R. and E. Kleinschmidt. The Impact of Export Strategy on Export Sales Performance, Journal of International Business Studies, Vol. 16, No. 1, pp. 37-55, 1985.

17. Daley, L. The Valuation of Reported Pension Measure for Firm Sponsoring Defined Benefit Plans, The Accounting Review, Vol. 59, No. 2, pp. 177-198, 1984.

18. Das, Somnath, Carolyn Levine, and K. Sivaramakrishnan. Earnings Predictions and Bias in Analysts' Earnings Forecasts, The Accounting Review, Vol. 73, No. 2, pp. 277-294, 1998.

19. Deakin, E. An Analysis of Differences Between Non-Major Oil Firms Using Successful Efforts and Full Cost Methods, Accounting Review, Vol. 54, No. 4, pp. 722-734. 1979.

20. Fama, Eugene and Kenneth French. The Cross-Section of Expected Stock Returns, Journal of Finance, Vol. 47, No. 2, pp. 427-465, 1992.

21. Foster, G. Accounting Policy Decisions and Capital Market Research, Journal of Accounting and Economics, Vol. 2, No. 1, pp. 29-62, 1980.

22. Foster, G. Quarterly Accounting Data: Time-Series Properties and Predictive-Ability Results, The Accounting Review, Vol. 52, No. 1, pp. 1-21, 1977.

23. Foster, G., C. Olsen, and T. Shevlin. Earnings Releases, Anomalies and the Behavior of Security Returns, The Accounting Review, Vol. 59, No. 4, pp. 574-603, 1984.

24. Holzmuller, H. and H. Kasper. On A Theory of Export Performance: Personal and organizational Determinants of Export Trade Activities Observed in Small and Medium-Sized Firms, Management International Review, Vol. 31, No. 1, pp. 45-70, 1991. 
25. Hughes, J. and W. Ricks, Accounting for Retail Land Sales: Analysis of a Mandated Change, Journal of Accounting and Economics, Vol. 6, No. 1, pp. 101-132, 1984.

26. Jensen, M. and W. MeCkling. Can the Corporation Survive? Financial Analyst Journal, Vol. 34, No. 1, pp. 31-37, 1978.

27. Kasznik, Ron and Muareen Mcnichols. Does Meeting Earnings Expectations Matter? Evidence from Analyst Forecast Revisions and Share Prices, Journal of Accounting Research, Vol. 40, No. 3, pp. 727-759, 2002.

28. Kaynak, E, and J. Kothari. Export Behavior of Small and Medium-Sized Manufacturers, Management International Review, Vol. 24, No. 2, pp. 61-69, 1984.

29. Kim, Dongcheol. A Reexamination of Firm Size, Book-to-Market, and Earnings Price in the Cross-Section of Expected Stock Returns, Journal of Financial and Quantitative Analysis, Vol. 32, No. 4, pp.463-489, 1997.

30. Kim, Dongcheol. The Errors-in-Variables Problem in the Cross-Section of Expected Stock Returns, Journal of Finance, Vol. 50, No. 5, pp.1605-1634, 1995.

31. Kousenidis, Dimitrios, Christos Negakis, and Iordanis Floropoulos. Size and Book-to-Market Factors in the Relationship between Average Stock Returns and Average Book Returns: Some Evidence from An Emerging Market, The European Accounting Review, Vol. 9, No. 2, pp. 225-243, 2000.

32. Kross, W. and D. Schoeder. Firm Prominence and the Differential Information Content of Quarterly Earnings Announcements, Journal of Business Finance and Accounting, Vol. 16, No. 1, pp. 55-74, 1989.

33. Lougee, Barabara and Carol Marquardt. Earnings Informativeness and Strategic Disclosure: An Empirical Examination of Pro Forma Earnings, The Accounting Review, Vol. 79, No. 3. pp. 769-795, 2004.

34. Moini, A. An Inquiry into Successful Exporting: An Empirical Investigation Using a Three-Stage Model, Journal of Small Business Management, Vol. 33, No. 3, pp. 9-25, 1995.

35. Reid, S. The Impact of Size on Export Behavior of Small Firms, in Export Management: An International Context, Ed. M.R. Czinkato and G. Tesar, New York, NY: Praeger, pp. 18-30, 1982.

36. Salamon, Gerald and Dan Dhaliwal. Company Size and Financial Disclosure Requirements With Evidence from the Segmental Reporting Issue, Journal of Business Finance \& Accounting, Vol. 7, No. 4, pp. 555-568, 1980.

37. Shehata, M. Self-Selection Bias and the Economic Consequences of Accounting Regulation: An Application of a Two-Stage Switching Regression to SFAS No. 2, The Accounting Review, Vol. 66, No. 4, pp. 768-787, 1991.

38. Shevlin, Terry and D. Shores. Firm Size, Security Returns, and Unexpected Earnings: The Anomalous Signed-Size Effect, Contemporary Accounting Research, Vol. 10, No. 1, pp. 1-30, 1993.

39. Stickel, R. Reputation and Performance among Security Analysts, Journal of Finance, Vol. 47, No. 5, pp. 1811-1836, 1992.

40. Watts, R. and J. Zimmerman. Toward A Positive Theory of the Determination of Accounting Standards, The Accounting Review, Vol. 53, No. 1, pp. 112-134, 1978.

41. Zimmerman, J. Taxes and Firm Size, Journal of Accounting and Economics, Vol. 5, No. 1, pp. 119-149, 1983.

42. Zmijewski, M. and R. Hagerman. An Income Strategy to the Positive Theory of Accounting Standard Setting Choice, Journal of Accounting and Economics, Vol. 3, No. 1, pp. 129-149, 1981.

\footnotetext{
${ }^{1}$ Total Assets represent current assets plus net plant plus noncurrent assets including intangible assets. Total sales revenue represents gross sales revenue reduced by cash discounts, trade discounts, and returned sales and allowances. Book value of equity equals common stock outstanding plus capital surplus plus retained earnings less treasury stock. Market value of equity is calculated by taking the number of common shares outstanding times the market value per share at fiscal year end.
} 
Table 1: List Of Sectors And Sample Size In Each Sector

\begin{tabular}{|l|c|}
\hline & Sample Size \\
\hline Energy (10) & 275 \\
\hline Materials (15) & 366 \\
\hline Industrials (20) & 816 \\
\hline Consumer Discretionary (25) & 967 \\
\hline Consumer Staples (30) & 255 \\
\hline Health Care 35 & 755 \\
\hline Financials 40 & 1110 \\
\hline Information Technology 45 & 1225 \\
\hline Telecommunication Services 50 & 155 \\
\hline Utilities & 133 \\
\hline Overall & 6057 \\
\hline
\end{tabular}

Table 2: Panel A - Correlation Coefficients For 1999

\begin{tabular}{|l|c|c|c|c|c|c|}
\hline & $\begin{array}{c}\text { SALE } \\
\text { \&TA }\end{array}$ & SALE \& BV & $\begin{array}{c}\text { SALE \& } \\
\text { MVE }\end{array}$ & TA \& BV & TA \& MVE & $\begin{array}{c}\text { BV \& } \\
\text { MVE }\end{array}$ \\
\hline Energy & 0.437091 & 0.667625 & 0.409585 & 0.493457 & 0.171407 & 0.514272 \\
\hline Materials & 0.410682 & 0.525979 & 0.174120 & 0.594956 & 0.599817 & 0.426426 \\
\hline Industrials & 0.545449 & 0.833258 & 0.570178 & 0.739027 & 0.322443 & 0.578317 \\
\hline Consumer Discretionary & 0.405801 & 0.457496 & 0.117877 & 0.610934 & 0.190068 & 0.478696 \\
\hline Consumer Staples & 0.624640 & 0.814228 & 0.283507 & 0.711607 & 0.180737 & 0.343164 \\
\hline Health Care & 0.484724 & 0.614989 & 0.276855 & 0.688289 & 0.278113 & 0.507344 \\
\hline Financials & 0.604012 & 0.603766 & 0.168561 & 0.796085 & 0.232746 & 0.374292 \\
\hline Information Technology & 0.683885 & 0.698681 & 0.420165 & 0.794997 & 0.478587 & 0.761276 \\
\hline Telecomm. Services & 0.897674 & 0.688016 & 0.354896 & 0.740704 & 0.473666 & 0.336385 \\
\hline Utilities & 0.424919 & 0.254387 & 0.379933 & 0.442273 & 0.425643 & 0.849934 \\
\hline Overall & 0.556588 & 0.603933 & 0.566090 & 0.545681 & 0.385493 & 0.616501 \\
\hline
\end{tabular}

Table 2: Panel B - Correlation Coefficients For 2000

\begin{tabular}{|l|c|c|c|c|c|c|}
\hline & $\begin{array}{c}\text { SALE } \\
\text { \&TA }\end{array}$ & SALE \& BV & $\begin{array}{c}\text { SALE \& } \\
\text { MVE }\end{array}$ & TA \& BV & TA \& MVE & $\begin{array}{c}\text { BV \& } \\
\text { MVE }\end{array}$ \\
\hline Energy & 0.447484 & 0.675532 & 0.523752 & 0.517456 & 0.312963 & 0.598951 \\
\hline Materials & 0.379882 & 0.441070 & 0.151873 & 0.569414 & 0.571369 & 0.348056 \\
\hline Industrials & 0.521366 & 0.803763 & 0.557009 & 0.706827 & 0.424542 & 0.647496 \\
\hline Consumer Discretionary & 0.336758 & 0.380708 & 0.102179 & 0.577873 & 0.185078 & 0.546874 \\
\hline Consumer Staples & 0.547503 & 0.713304 & 0.234587 & 0.630440 & 0.249363 & 0.688017 \\
\hline Health Care & 0.376084 & 0.572145 & 0.216217 & 0.599417 & 0.265926 & 0.547025 \\
\hline Financials & 0.522263 & 0.474976 & 0.210258 & 0.812382 & 0.419883 & 0.613526 \\
\hline Information Technology & 0.610501 & 0.687776 & 0.504420 & 0.769929 & 0.467245 & 0.758666 \\
\hline Telecomm. Services & 0.776887 & 0.670935 & 0.635153 & 0.975066 & 0.924063 & 0.925257 \\
\hline Utilities & 0.452329 & 0.351976 & 0.474534 & 0.474534 & 0.493062 & 0.898889 \\
\hline Overall & 0.575954 & 0.662963 & 0.656612 & 0.576687 & 0.496513 & 0.696158 \\
\hline
\end{tabular}


Table 2: Panel C - Correlation Coefficients For 2001

\begin{tabular}{|l|c|c|c|c|c|c|}
\hline & SALE \&TA & SALE \& BV & SALE \& MVE & TA \& BV & TA \& MVE & BV \& MVE \\
\hline Energy & 0.424892 & 0.583366 & 0.564106 & 0.491195 & 0.346184 & 0.661482 \\
\hline Materials & 0.380999 & 0.444333 & 0.318546 & 0.579547 & 0.381324 & 0.547729 \\
\hline Industrials & 0.456727 & 0.708101 & 0.617631 & 0.819601 & 0.627475 & 0.811163 \\
\hline Consumer Discretionary & 0.316393 & 0.414929 & 0.218609 & 0.540531 & 0.282791 & 0.708789 \\
\hline Consumer Staples & 0.487821 & 0.662412 & 0.371974 & 0.596164 & 0.344821 & 0.790095 \\
\hline Health Care & 0.521525 & 0.724965 & 0.533476 & 0.652999 & 0.475191 & 0.821154 \\
\hline Financials & 0.535662 & 0.517263 & 0.397124 & 0.840976 & 0.614456 & 0.809328 \\
\hline Information Technology & 0.510118 & 0.628783 & 0.520501 & 0.704756 & 0.468261 & 0.811266 \\
\hline Telecomm. Services & 0.841184 & 0.771174 & 0.726942 & 0.977306 & 0.741419 & 0.712157 \\
\hline Utilities & 0.446486 & 0.462834 & 0.590028 & 0.404757 & 0.472832 & 0.893804 \\
\hline Overall & 0.559321 & 0.653199 & 0.699743 & 0.578685 & 0.518147 & 0.744153 \\
\hline
\end{tabular}

Table : Panel D - Correlation Coefficients For 2002

\begin{tabular}{|l|c|c|c|c|c|c|}
\hline & SALE \&TA & SALE \& BV & SALE \& MVE & TA \& BV & TA \& MVE & BV \& MVE \\
\hline Energy & 0.383961 & 0.619651 & 0.575651 & 0.564044 & 0.335101 & 0.755138 \\
\hline Materials & 0.313716 & 0.481817 & 0.295263 & 0.601201 & 0.348044 & 0.487393 \\
\hline Industrials & 0.419918 & 0.604673 & 0.574731 & 0.827043 & 0.711041 & 0.884975 \\
\hline Consumer Discretionary & 0.245732 & 0.350668 & 0.236911 & 0.463213 & 0.314594 & 0.702134 \\
\hline Consumer Staples & 0.383362 & 0.440806 & 0.336866 & 0.609198 & 0.525873 & 0.826195 \\
\hline Health Care & 0.418385 & 0.617212 & 0.555421 & 0.511241 & 0.447336 & 0.744223 \\
\hline Financials & 0.078295 & 0.053605 & 0.085473 & 0.529863 & 0.714165 & 0.607314 \\
\hline Information Technology & 0.492426 & 0.585221 & 0.585221 & 0.600152 & 0.415759 & 0.794947 \\
\hline Telecomm. Services & 0.869839 & 0.313826 & 0.666929 & 0.338997 & 0.773981 & 0.452462 \\
\hline Utilities & 0.451214 & 0.601492 & 0.735027 & 0.386894 & 0.509397 & 0.868017 \\
\hline Overall & 0.527178 & 0.659863 & 0.711219 & 0.597174 & 0.512472 & 0.772669 \\
\hline
\end{tabular}

Table 3: Panel A - Descriptive Statistics - SALE 1999

\begin{tabular}{|l|c|c|c|c|}
\hline & Mean & Median & Kurtosis & Skewness \\
\hline Energy & 709.44 & 106.34 & 129.40 & 10.52 \\
\hline Materials & 1645.22 & 373.38 & 24.44 & 4.53 \\
\hline Industrials & 1969.93 & 188.33 & 162.03 & 11.76 \\
\hline Consumer Discretionary & 2189.25 & 276.94 & 165.166 & 11.64 \\
\hline Consumer Staples & 4492.54 & 370.57 & 85.85 & 7.90 \\
\hline Health Care & 793.19 & 18.88 & 47.98 & 6.506 \\
\hline Financials & 1411.4 & 79.32 & 74.52 & 7.72 \\
\hline Information Technology & 858.37 & 50.32 & 165.05 & 11.45 \\
\hline Telecomm. Services & 3956.15 & 238.63 & 30.63 & 5.00 \\
\hline Utilities & 3378.10 & 1194.38 & 24.58 & 4.20 \\
\hline Overall & 1715.80 & 101.56 & 200.98 & 12.11 \\
\hline
\end{tabular}


Table 3: Panel B - Descriptive Statistics - TA 1999

\begin{tabular}{|l|c|c|c|c|}
\hline & Mean & Median & Kurtosis & Skewness \\
\hline Energy & 3170.60 & 237.98 & 71.91 & 7.76 \\
\hline Materials & 2305.46 & 419.53 & 20.12 & 4.04 \\
\hline Industrials & 2425.22 & 164.21 & 472.28 & 20.19 \\
\hline Consumer Discretionary & 2628.22 & 236.29 & 237.40 & 14.20 \\
\hline Consumer Staples & 3007.72 & 295.75 & 34.45 & 5.17 \\
\hline Health Care & 1106.07 & 36.45 & 175.40 & 12.06 \\
\hline Financials & 13833.54 & 640.22 & 68.69 & 7.74 \\
\hline Information Technology & 936.38 & 71.23 & 172.62 & 11.75 \\
\hline Telecomm. Services & 9809.17 & 770.48 & 31.85 & 5.29 \\
\hline Utilities & 7651.56 & 2842.58 & 6.052 & 2.41 \\
\hline Overall & 4437.61 & 198.37 & 304.42 & 15.79 \\
\hline
\end{tabular}

Table 3: Panel C - Descriptive Statistics - BV 1999

\begin{tabular}{|c|c|c|c|c|}
\hline & Mean & Median & Kurtosis & Skewness \\
\hline Energy & 1230.55 & 80.65 & 85.60 & 9.00 \\
\hline Materials & 822.77 & 150.33 & 26.88 & 4.74 \\
\hline Industrials & 600.47 & 96.60 & 185.36 & 12.02 \\
\hline Consumer Discretionary & 797.81 & 86.06 & 159.65 & 10.84 \\
\hline Consumer Staples & 942.94 & 83.45 & 36.92 & 5.30 \\
\hline Health Care & 363.43 & 19.64 & 81.99 & 8.16 \\
\hline Information Technology & 440.53 & 47.39 & 118.90 & 9.89 \\
\hline Telecomm. Services & 4459.84 & 1607.33 & 96.83 & 9.21 \\
\hline Utilities & 2110.19 & 847.58 & 20.26 & 3.87 \\
\hline Overall & 832.97 & 66.12 & 1132.24 & 26.03 \\
\hline
\end{tabular}

Table 3: Panel D - Descriptive Statistics - MVE 1999

\begin{tabular}{|c|c|c|c|c|}
\hline & Mean & Median & Kurtosis & Skewness \\
\hline Energy & 3748.48 & 137.49 & 115.61 & 10.24 \\
\hline Materials & 1988.53 & 203.47 & 50.33 & 6.18 \\
\hline Industrials & 2251.54 & 103.84 & 561.54 & 22.27 \\
\hline Consumer Discretionary & 2692.71 & 146.63 & 121.80 & 10.01 \\
\hline Consumer Staples & 8037.96 & 144.70 & 117.53 & 10.15 \\
\hline Health Care & 2363.65 & 89.11 & 72.35 & 8.13 \\
\hline Information Technology & 4605.42 & 213.05 & 238.50 & 13.49 \\
\hline Telecomm. Services & 20580.32 & 1419.11 & 16.72 & 3.97 \\
\hline Utilities & 3310.42 & 1221.28 & 27.62 & 4.5 \\
\hline Overall & 3701.21 & 144.48 & 272.55 & 14.29 \\
\hline
\end{tabular}


Table 4: Test For Equality Of Variances And Means

\begin{tabular}{|c|c|c|c|c|}
\hline & Bartlett & Levene & ANOVA F Stat. & Kruskal-Wallis \\
\hline SALE1999 & 2244.05 & 20.14 & 9.73 & 648.79 \\
\hline SALE2000 & 2374.62 & 23.35 & 12.13 & 691.15 \\
\hline SALE2001 & 2482.34 & 26.64 & 13.19 & 619.73 \\
\hline SALE2002 & 2267.38 & 24.93 & 11.15 & 602.59 \\
\hline TA1999 & & & 16.26 & 987.29 \\
\hline TA2000 & 10110.58 & 48.55 & 16.74 & 1102.62 \\
\hline TA2001 & 12207.80 & 49.46 & 17.73 & 923.62 \\
\hline TA2002 & 13650.49 & 52.47 & 16.88 & \\
\hline BV1999 & 11552.92 & 50.90 & & 407.97 \\
\hline BV2000 & 5389.01 & & 16.25 & 321.72 \\
\hline BV2001 & 4465.17 & 40.41 & 17.73 & 339.60 \\
\hline BV2002 & 3907.77 & 45.47 & 12.80 & 327.20 \\
\hline MVE1999 & 3531.73 & 32.39 & 10.77 & \\
\hline MVE2000 & & 27.79 & & 232.00 \\
\hline MVE2001 & 1648.23 & & 13.33 & 190.81 \\
\hline MVE2002 & 1382.03 & 17.67 & 6.82 & 184.03 \\
\hline
\end{tabular}

